Lactococcus lactis subsp. cremoris FCで発酵したヨーグルトが高校陸上長距離選手の 唾液中分泌型免疫グロブリン Aの分泌に与える影響

後藤 弥生 ${ }^{1}$, 小阪 英樹 $^{1}$, 相磯 知里 ${ }^{1}$, 吉田 克久 ${ }^{2}$, 本山 司 $^{3}$, 本山 貢 ${ }^{4}$, 鈴木 利雄 $^{{ }^{*}}$

\title{
Effect of yogurt fermented with Lactococcus lactis subsp. cremoris FC on salivary secretory IgA levels in high school-student long-distance runners
}

\author{
Yayoi Gotoh $^{1}$, Hideki Kosaka ${ }^{1}$, Chisato Aiso ${ }^{1}$, Katsuhisa Yoshida ${ }^{2}$, Tsukasa Motoyama ${ }^{3}$, \\ Mitsugi Motoyama ${ }^{4}$ and Toshio Suzuki ${ }^{{ }^{*}}$
}

\begin{abstract}
1 フジッコ株式会社，７650-8558 兵庫県神戸市中央区港島中町6-13-4 (Fujicco Co., Ltd., 6-13-4 Minatojima-nakamachi, Chuo-ku, Kobe City, Hyogo 650-8558, Japan)

2 和歌山北高等学校， ₹ 640-0112 和歌山県和歌山市西庄 1148-1 (Wakayama-Kita High School, 1148-1 Nishinosho, Wakayama City, Wakayama 640-0112, Japan)

3 東亜大学人間科学部スポーツ健康学科, ₹751-8503 山口県下関市一の宮学園町2-1 (Department of Sport and Health Sciences, Faculty of Human Sciences, University of East Asia, 2-1 Ichinomiya-gakuencho, Shimonoseki City, Yamaguchi 751-8503, Japan)

${ }^{4}$ 和歌山大学教育学部， ₹640-8510 和歌山県和歌山市栄谷930 (Faculty Education, Wakayama University, 930 Sakaedani, Wakayama City, Wakayama 640-8510, Japan)
\end{abstract}

Received: April 15, 2019 / Accepted: August 16, 2019

\begin{abstract}
In athletes, repeated intensive exercise is considered to depress the immune system. The purpose of this study was to investigate the effects of yogurt fermented with Lactococcus lactis subsp. cremoris FC (L. cremoris FC) on salivary secretory immunoglobulin A (SIgA) in long-distance runners (high school students) during a 5 day intensive training program. Fourteen subjects were divided into 2 groups: a yogurt fermented with L. cremoris FC intake group and a milk intake group (control group). Each subject consumed yogurt or milk for 5 days during the intensive training. Salivary samples were obtained on days 1 and 5, and SIgA secretion and cortisol levels were measured. In addition, the mood of each subject was evaluated using the Profile of Mood States (POMS) questionnaire. Our study suggested that L. cremoris FC intake increases SIgA secretion. In addition, there might be a significant suppression in the increase of salivary cortisol levels caused by exercise mainly, but there was no effect on mood. These results suggest that $L$. cremoris FC intake may have health benefits by enhancing oral immune function mediated by SIgA.
\end{abstract}

Jpn J Phys Fitness Sports Med, 68(6): 407-414 (2019)

Keywords : lactic acid bacteria, secretory immunoglobulin A, athlete

\section{緒言}

アスリートは, パフォーマンスの向上を目的に高強度 トレーニングを行っている。しかし, 高強度運動の繰り 返しは疲労を蓄積させ, コンディションの低下を引き起 こすことが問題とされている. 特にアスリートのコン ディションを低下させる要因の一つとして免疫機能の低 下が挙げられ，マラソンレース後のアスリートにおいて 上気道感染症への罹患リスクが 2 〜 倍に高まることが 報告されている1,2).

*Correspondence: t-suzuki@fujicco.co.jp
上気道感染症への感染防御には口腔内局所免疫が関与 し，特にSIgAが重要な役割を果たす．SIgAはウイルス や細菌が体内に侵入することを防ぐ役割を持つ. SIgA は高強度運動によって低下することが報告されており ${ }^{3)}$, 長距離陸上選手においてもウルトラマラソン後の唾液

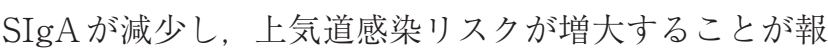
告されている ${ }^{4)}$ ，そのため, 先行研究に打いて SIgA分泌 の変動はコンディション評価の客観的な指標として用い られている5,

アスリートが乳酸菌を摂取することで，SIgA分泌を はじめとしたコンディション向上作用が得られることが 示されている，大学ラグビー選手におけるLactobacillus 
gasseri OLL2809の摂取試験で，9週間の継続摂取によ り唾液 SIgA濃度の上昇や感冒症状の出現日数が短縮さ れること ${ }^{7)}$, さらに 4 週間の摂取により NK 活性の低下 抑制や心理状態の改善が報告されている8)。 また, 長距 離陸上選手を対象としたLactobacillus fermentum VRI003の 4 カ月間の摂取試験では感冒症状の重症度や継 続期間が減少すること ${ }^{9}$, 、ラソン選手を対象とした Lactobacillus rhamnosus GGの 3 カ月間の摂取試験では レース後の胃腸症状有訴期間が短縮されることが報告さ れている10). しかし，これらはいずれも長期間の継続摂 取試験による結果であり， 1 週間以内の短期摂取による 乳酸菌のアスリートへの効果は報告されていない.

Lactococcus lactis subsp. cremoris FC (L. cremoris FC）はコーカサス地方を由来とする乳酸菌で，日本にお いてヨーグルトの製造に利用されている ${ }^{11)}$. L. cremoris $\mathrm{FC}$ で作製したヨーグルトは一般的なヨーグルトと比較 して強い粘りを持ち, この粘りはL cremoris FCが産生 する菌体外多糖（Exopolysaccharide：EPS）に由来す る。我々はこれまでにマウスにおける投与試験にてL. cremoris FCがインフルエンザウイルス感染後の肺中ウ イルスカ価を減少させ, 生存率を向上させることを報告 している ${ }^{12)}$ 。また, L. cremoris FCのEPSが小腸に存在 する免疫器官であるパイエル板細胞に作用し, 粘膜免疫 に働きかけることを明らかとしている13)。よって, 高強 度運動による免疫力低下に対しても，L. cremoris FCの 摂取が作用することが期待される，そこで本研究では高 校陸上長距離選手を対象とし，5日間の強化練習期間 に扔いてL. cremoris FCの摂取が崜液SIgA 分泌やコン ディションに及ぼす影響について検討した。

\section{方法}

対象 W県立高校の男子陸上部に所属する長距離選手 14名を対象とした，対象者はアンケートにより事前に年 齢, 身長, 体重の調查を実施し, ランダムに 2 つのグルー プに分けた。なお，全ての対象者およびその代諾者に事 前に実験の趣旨や手順を説明し, 研究参加の同意を得た. 本研究は「ヘルシンキ宣言」の趣旨に従い,「フジッコ
株式会社倫理委員会」の承認を得て実施した（承認番号： 5901番).

試験食品 試験食としてL. cremoris FCを含む固形ヨー グルト，対照食として牛乳を用いた。 ヨーグルトは $L$. cremoris FC (フジッコ) およびStreptococcus thermophilus（S. thermophilus）ST117（Sacco）の 2 つの乳酸菌 を用いて作製した。作製したヨーグルトには各乳酸菌が $1 \times 10^{7}$ colony forming unit $(\mathrm{cfu}) / \mathrm{g}$ 以上含まれていた.

試験デザイン この試験は 2018年12月 24日から 2018年 12 月 28 日に実施した。被験者 14 名を対照群 7 名, ヨー グルト群 7 名に分けた. Table 1 に被験者情報を示した が, 年齢, 身長, 体重, BMIに差異は無かった。なお, 被験者の盲検化は行わなかった。

試験食は試験期間の 5 日間摂取してもらった。1日目 は摂取前検查終了後に摂取してもらい，2 日目以降と最 終日の 5 日目までは朝食後にそれぞれ $100 \mathrm{~g}$ の試験食を 摂取してもらった。 また, 試験期間には強化練習を行い, 通常よりも負荷の強いトレーニングを実施した。その強 化トレーニング内容と実施前の普段のトレーニング内容 をTable 2 に示した。 なお，全被験者が同じトレーニン グを行った。試験開始 1 週間前から試験終了日までは, 他のヨーグルトや牛乳の摂取を出来るだけ控えてもらっ た以外は特に食事制限は行わなかった。唾液の採取㧍よ びアンケート調查を 1 日目 (試験食摂取前) と 5 日目（試 験食摂取後）の 2 回実施した.

唾液の採取および成分検査 唾液採取の 2 時間前からは 飲食やはみがきを避けるよう被験者に指示し，運動前の 午前 8 時から 9 時の間に唾液を採取した。唾液の採取に はSalimetrics Oral Swab（SOS, Salimetrics社）を使用 した，座位安静時にSOSを 1 分間舌下にはさみ，分泌さ れた唾液をSOSにしみ込ませて採取した。SOSはSwab Strage Tube（Salimetrics社）に入れ，直ちに $4{ }^{\circ} \mathrm{C} に$ 冷 却した。当日中に $3,000 \mathrm{rpm}$ で15分間遠心して唾液を収 集し，得られた唾液の重量を測定した。唾液の比重を 1

Table 1. Characteristics of subjects.

\begin{tabular}{lccc}
\hline & Control $(\mathrm{n}=7)$ & Yogurt $(\mathrm{n}=7)$ & \\
\hline Age (years) & $16.1 \pm 0.7$ & $16.0 \pm 0.6$ & $\mathrm{~ns}$ \\
Hight $(\mathrm{cm})$ & $170.0 \pm 7.1$ & $166.4 \pm 6.3$ & $\mathrm{~ns}$ \\
Weight $(\mathrm{kg})$ & $55.7 \pm 4.1$ & $51.3 \pm 6.2$ & $\mathrm{~ns}$ \\
BMI $\left(\mathrm{kg} / \mathrm{m}^{2}\right)$ & $19.3 \pm 1.6$ & $18.5 \pm 1.6$ & $\mathrm{~ns}$ \\
\hline
\end{tabular}

Values are expressed as mean \pm SE. ns, not significant. 
Table 2. Comparison between intensive and normal training

\begin{tabular}{|c|c|c|c|c|}
\hline \multirow[b]{2}{*}{ Date } & \multicolumn{4}{|c|}{ Exercise contents } \\
\hline & \multicolumn{2}{|r|}{ Intensive training } & \multicolumn{2}{|r|}{$\begin{array}{c}\text { Normal training } \\
\text { (performed just before intensive } \\
\text { training) }\end{array}$} \\
\hline \multirow{2}{*}{$\begin{array}{l}\text { First day*1) } \\
\quad(\text { Dec } 24)\end{array}$} & am & $\begin{array}{l}\text { 1) } 8000-\mathrm{m} \text { jog } \\
\text { 2) } 600-\mathrm{m} \text { run }(10 \text { sets })\end{array}$ & am & 1000 -m run (6 sets) \\
\hline & $\mathrm{pm}$ & 1) $20-\mathrm{km}$ road run & $\mathrm{pm}$ & - \\
\hline \multirow{2}{*}{$\begin{array}{l}\text { Second day } \\
\text { (Dec 25) }\end{array}$} & $\mathrm{am}$ & $\begin{array}{l}\text { 1) } 4000-\mathrm{m} \text { jog } \\
\text { 2) } 2000-\mathrm{m} \text { run }(4 \text { sets }) \\
\text { 3) } 1000-\mathrm{m} \text { run }(1 \text { set })\end{array}$ & $\mathrm{am}$ & $\begin{array}{l}\text { Runs }(6000,4000,2000, \text { and } \\
1000 \mathrm{~m})\end{array}$ \\
\hline & $\mathrm{pm}$ & $\begin{array}{l}\text { 1) Jog for } 60 \mathrm{~min} \text { at } 6 \mathrm{~min} / \mathrm{km} \text { of sandy beach } \\
\text { 2) } 100-\mathrm{m} \text { run }(10-15 \mathrm{sets}) \text { on sandy beach }\end{array}$ & $\mathrm{pm}$ & - \\
\hline \multirow[t]{2}{*}{$\begin{array}{l}\text { Third day } \\
\text { (Dec 26) }\end{array}$} & am & $\begin{array}{l}\text { 1) Power MAX training (Tabata's method) } \\
\text { ( } 7 \text { sets) } \\
\text { 2) } 12-\text { to } 14-\mathrm{km} \text { jog }\end{array}$ & $\mathrm{am}$ & 40-min free jog \\
\hline & $\mathrm{pm}$ & 1) 40-min jog & $\mathrm{pm}$ & - \\
\hline \multirow{2}{*}{$\begin{array}{l}\text { Forth day } \\
\text { (Dec 27) }\end{array}$} & am & $\begin{array}{l}\text { 1) } 4000-\mathrm{m} \text { run (3 sets) on an outdoor course } \\
\text { 2) } 9000-\mathrm{m} \text { repeated up/down jog }\end{array}$ & $\mathrm{am}$ & $18-\mathrm{km}$ road run \\
\hline & $\mathrm{pm}$ & 1) $18000-\mathrm{m}$ free jog for $90 \mathrm{~min}$ & $\mathrm{pm}$ & - \\
\hline \multirow{2}{*}{$\begin{array}{l}\text { Fifth day*2) } \\
(\text { Dec } 28)\end{array}$} & am & 1) $30-\mathrm{km}$ outdoor run & $\mathrm{am}$ & 10-km free jog \\
\hline & $\mathrm{pm}$ & - & $\mathrm{am}$ & - \\
\hline
\end{tabular}

${ }^{* 1,2)}$ Saliva sampling was performed on the first and fifth days before intensive training, respectively.

として 1 分間当たりの唾液分泌量を算出した．唾液は 1.5 $\mathrm{ml}$ チューブに分注後, 測定に使用するまで $-20^{\circ} \mathrm{C} て ゙$ 保存 した。唾液成分はSIgAとコルチゾールを分析した。分 析にはそれぞれSecretory Immunoglobulin A Salivary Immunoassay Kit (Salimetrics 社), Cortisol Salivary Immunoassay Kit (Salimetrics社)を用いた. SIgAにつ いては, 唾液分泌量 $(\mathrm{ml} / \mathrm{min})$ と SIgA 濃度 $(\mu \mathrm{g} / \mathrm{ml})$ との積を SIgA 分泌速度（ $\mu \mathrm{g} / \mathrm{min} ）$ として示した。

心理状態の調査 心理プロフィール検査 (Profile of Mood States 2nd Edition: POMS2, 青少年用全項目版) を用いて，今現在どのように感じているかを回答用紙に 記入してもらった. 採点後, 怒り一敵意, 混乱一当惑, 抑うつ一落込从, 疲労一無気力, 緊張一不安, 活気 - 活 力, 友好の 7 尺度と, Total Mood Disturbance (TMD) 得点を評価した. POMSで得た得点は, $\mathrm{T}$ 得点（ $\mathrm{T}$ 得点 $=50+10 \times($ 素得点 - 平均値 $) /$ 標準偏差 $)$ に換算し標準 化した.

統計解析 各測定值は平均值土標準誤差で示した。対 照群とヨーグルト群の比較には対応の無い $\mathrm{t}$ 検定を用 い，各群に打ける撖取期間前後の差には対応のある $\mathrm{t}$ 検 定を用いた，有意水準は $5 \%$ 未満とした。統計解析には JMP14.1（SAS Institute）を使用した。

\section{結果}

唾液SIgA 唾液分泌速度, 唾液SIgA濃度, およびSIgA 分泌速度の変化をFig. 1に示した. SIgA濃度は, 対照群 では摂取前後で差が無かったのに対し、ヨーグルト群で は摂取により有意に増加した $(p<0.001)$ （Fig. 1b）。唾 液分泌速度㧍よびSIgA 分泌速度は摂取前後を比較する と両群ともに有意差は無かった（Fig. 1a, 1c)。また，唾 液 SIgA 濃度と SIgA 分泌速度の変化量を群間比較した (Fig. 2).SIgA 濃度の変化量は群間に差はなかったが (Fig. 2a), SIgA分泌速度の変化量は対照群よりもヨー グルト群が有意に多かった（ $p<0.05 ） （$ Fig. 2b).

唾液コルチゾール Fig. 3 に結果を示した。コルチゾー ルは対照群, ヨーグルト群共に摂取後に増加したが, 対照群でのみ摂取前と比べて有意な差が認められた $(p<0.01)$.

心理状態 Table 3にPOMSスコアを示したが，どの尺 度にも差は無かった。

\section{考察}

本研究では高校陸上長距離選手を対象に，5日間の強 化練習期間に执いてL. cremoris FCを含むヨーグルト 
(a)
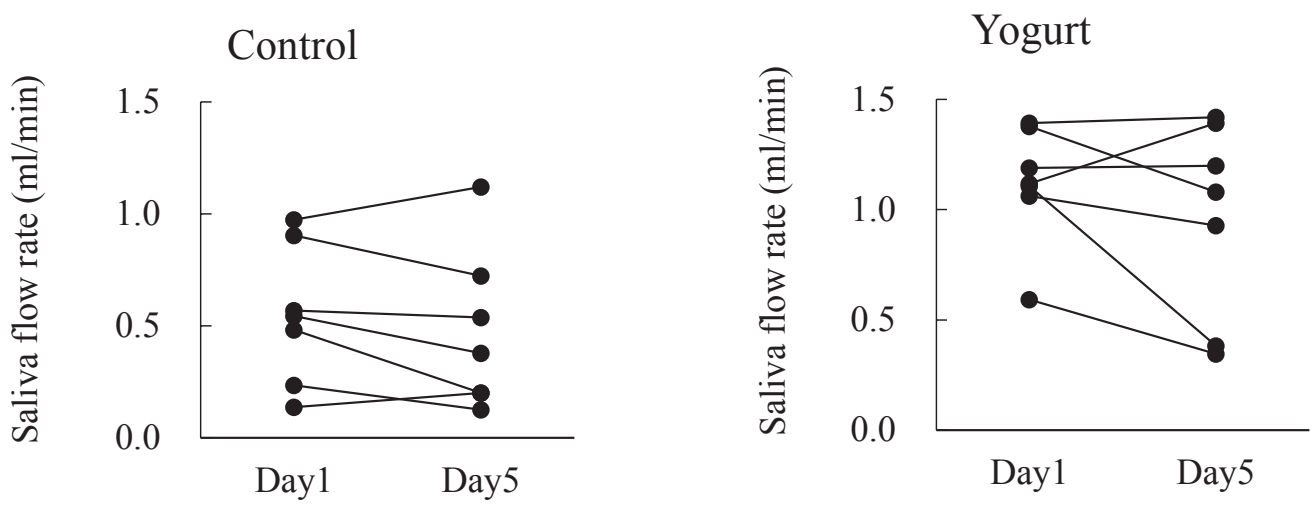

(b)

Control

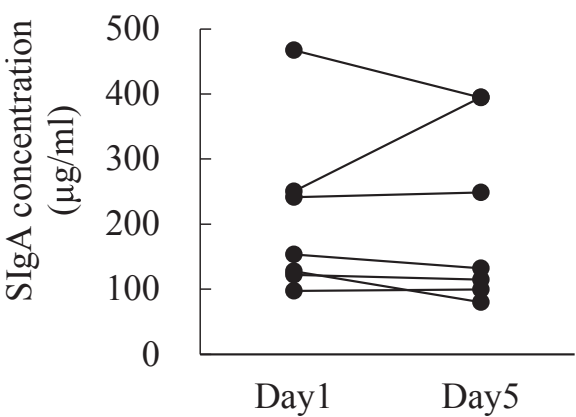

(c)

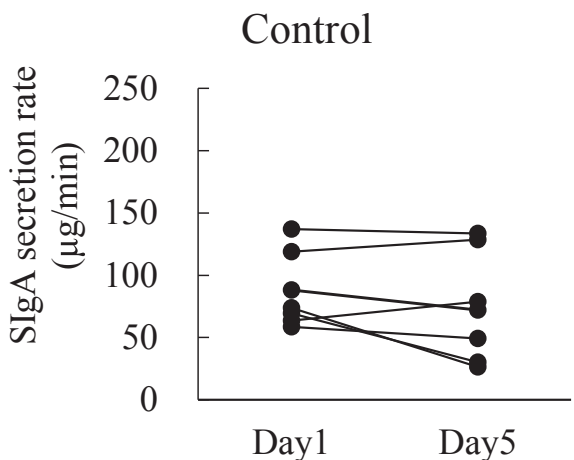

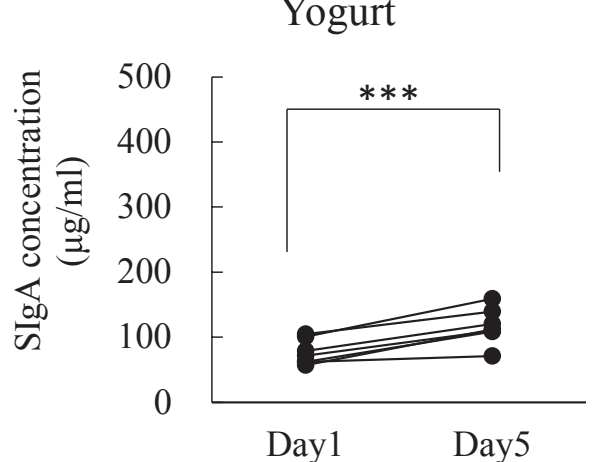

Yogurt

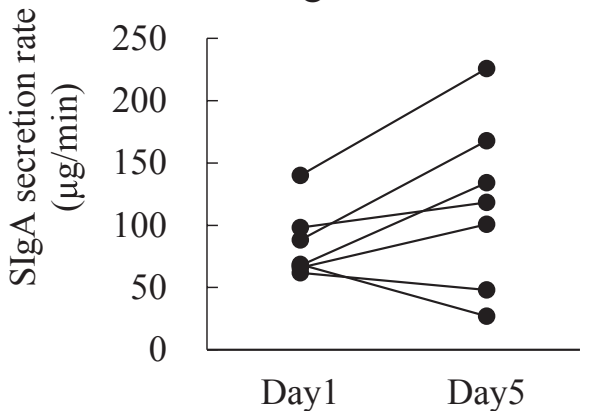

Fig. 1 Changes in saliva flow rate (a), salivary secretory immunoglobulin A concentration (b), and salivary secretory immunoglobulin A secretion rate (c).

Values are expressed as mean $\pm \mathrm{SE}$.

***: Significant difference from dayl within group by Student's paired $t$ test at $p<0.001$.

の摂取が唾液SIgA 分泌やコンディションに及ぼす影響 について検討した。その結果，L. cremoris FCの摂取に より唾液SIgA分泌が高まる可能性が示唆された。また, 運動負荷による唾液コルチゾールの有意な増加が抑制さ れた。

高強度運動による免疫力の低下が問題とされるアス リートに打いて, 乳酸菌による免疫調節力を通じたコン ディションの向上が既に報告されている。 大学ラグビー 選手を対象としたLactobacillus gasseri OLL2809の摂取
試験により，乳酸菌加熱死菌体を $1 \times 10^{10}$ 個含むタブレッ 卜を 9 週間継続摂取することで唾液 SIgA 濃度の上昇や 感冒症状の出現日数が短縮されること ${ }^{7)} ， 4$ 週間継続摂 取することでNK 活性の低下抑制や心理状態の改善が報 告されている ${ }^{8)}$ 。また, Lactobacillus fermentum VRI003 を $1 \times 10^{10} \mathrm{cfu}$ を含むカプセルを 4 か月間摂取する事 で長距離ランナーの感冒症状の重症度や継続期間が減る ことが報告されており ${ }^{9)}$ ，Lactobacillus rhamnosus GG ではマラソンランナーが $4 \times 10^{10} \mathrm{cfu}$ 含む乳飲料を 3 カ月 
(a)

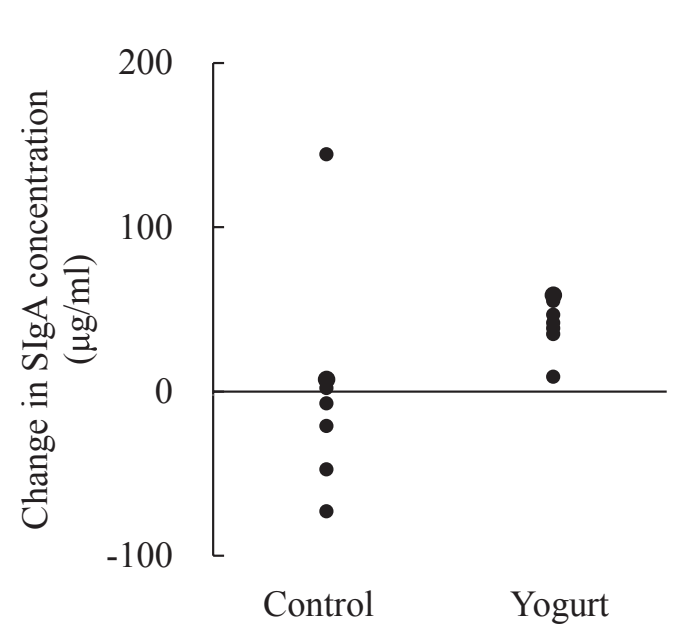

(b)

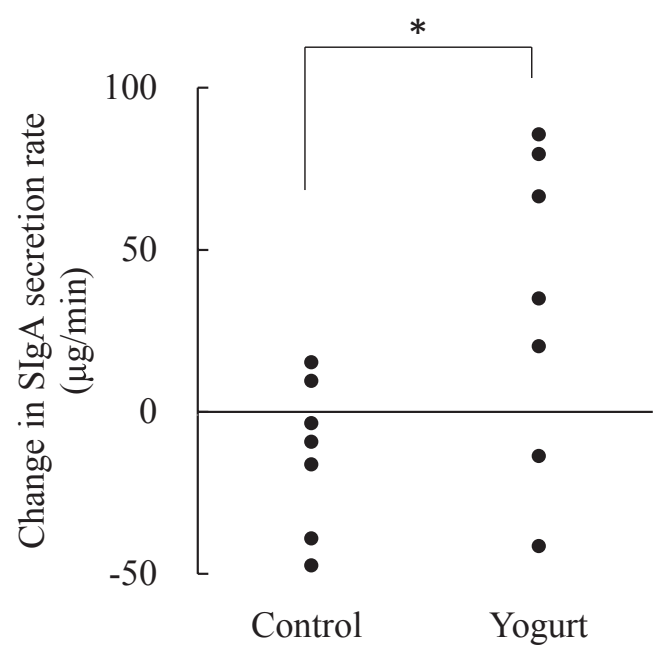

Fig. 2 Change values of saliva flow rate, salivary secretory immunoglobulin A concentration (a), and salivary secretory immunoglobulin A secretion rate (b).

*: Significant difference from control group by Student's unpaired $t$-test at $p<0.05$.
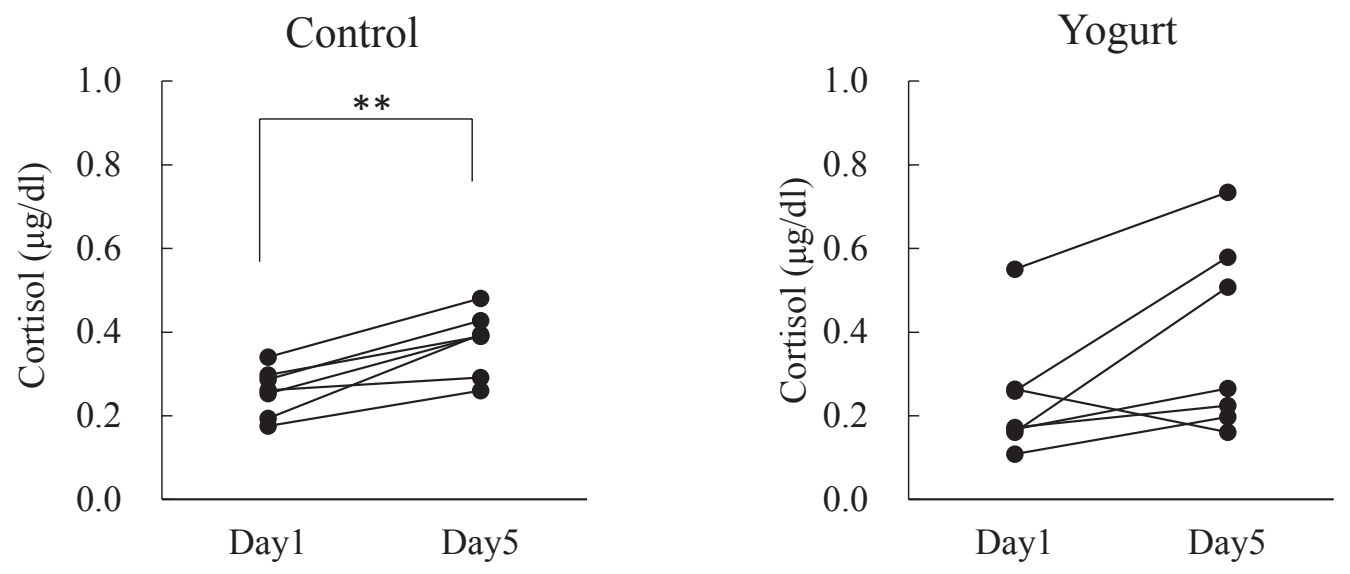

Fig. 3 Changes in salivary cortisol concentration.

Values are expressed as mean $\pm \mathrm{SE}$.

**: Significant difference from day 1 within group by Student's paired $t$ test at $p<0.01$.

間摂取する事でレース後に胃腸症状を訴える期間が短縮 されることが報告されている10)。ささらに，アスリート以 外を対象とした乳酸菌の唾液SIgA 分泌促進作用につい て言及すると, Lactobacillus pentosus strain b240が成人 女性や運動習慣のある高齢者に扔いて, 前者では 3 週間, 後者では 12 週間, $2 \times 10^{9} \mathrm{cfu}$ 含む飲料を継続摂取するこ とで唾液 $\mathrm{SIgA}$ 分泌を高めることが報告されている ${ }^{14,15)}$. Lactobacillus casei Shirotaでは運動習慣のある成人男 女に対する 16 週間の摂取試験でトレーニングによる唾 液SIgA 濃度の低下抑制を報告している16)。今回の試験 でのL. cremoris FCの摂取量は 1 日当たり $1 \times 10^{9}$ から $10^{10} \mathrm{cfu}$ とこれでの報告と同等であったが，5 日間と いう短期間でアスリートの唾液 SIgA分泌が高まる可能
性が示唆された.

我々はこれまでにL. cremoris FCの摂取により感染 防御作用が得られることを報告してきた，マウスに执い てL. cremoris FCの経口投与がインフルエンザウイルス 感染後の肺中ウイルス力価を減少させ, 生存率を向上さ せることを報告している ${ }^{12)}$ ，また，重症心身障がい者 を対象とした摂取試験に扔いて, L. cremoris FC乳酸菌 摂取群では, プラセボ群に対しインフルエンザワクチン の抗体価が有意に上昇することを報告している ${ }^{17)}$ 。唾 液SIgA は上気道感染症への感染防御に重要な役割を果 たす。前述した通り, Lactobacillus pentosus strain b240 の摂取により唾液SIgA 分泌が促進することが明らかと なっているが, このメカニズムとして小腸パイエル板を 
Table 3. Profile of Mood States (POMS) T score.

\begin{tabular}{lccccc}
\hline & \multicolumn{2}{c}{ Control } & & \multicolumn{2}{c}{ Yogurt } \\
\cline { 2 - 3 } \cline { 5 - 6 } \cline { 5 - 6 } & Day1 & Day5 & & Day1 & Day5 \\
\hline Anger-Hostility & $8.6 \pm 1.7$ & $5.4 \pm 2.4$ & & $7.4 \pm 2.7$ & $5.3 \pm 2.1$ \\
Confusion-Bewilderment & $7.6 \pm 1.8$ & $8.6 \pm 2.9$ & & $8.0 \pm 1.5$ & $6.4 \pm 1.3$ \\
Depression-Dejection & $4.4 \pm 1.5$ & $4.3 \pm 2.0$ & & $6.1 \pm 1.3$ & $5.7 \pm 1.7$ \\
Fatigue-Inertia & $9.6 \pm 2.2$ & $6.9 \pm 2.3$ & & $10.4 \pm 1.7$ & $8.1 \pm 2.2$ \\
Tension-Anxiety & $10.9 \pm 3.3$ & $8.6 \pm 4.5$ & & $10.0 \pm 2.5$ & $8.3 \pm 1.9$ \\
Vigor-Activity & $24.7 \pm 2.1$ & $23.1 \pm 2.6$ & & $21.9 \pm 1.3$ & $22.1 \pm 2.0$ \\
Friendliness & $14.4 \pm 1.6$ & $13.7 \pm 1.7$ & & $11.1 \pm 1.6$ & $12.6 \pm 1.5$ \\
TMD score & $16.3 \pm 8.4$ & $10.6 \pm 11.2$ & & $20.1 \pm 8.9$ & $11.7 \pm 9.3$ \\
\hline
\end{tabular}

Values are expressed as mean \pm SE.

通じた免疫調節が挙げられている. Lactobacillus pentosus strain b240をマウスパイエル板細胞へ添加培養する と, SIgA 産生が増加することが報告されている ${ }^{18)}$ ，パ イエル板には樹状細胞, $\mathrm{T}$ 細胞, $\mathrm{B}$ 細胞等の多様な免疫 細胞が存在する。M細胞からパイエル板へ取り込まれた 抗原により樹状細胞の受容体が刺激されると, B 細胞が 抗体産生細胞へと分化する。 パイエル板でできた抗体産 生細胞は腸だけでなく、口腔や肺などへも移行し IgAを 産生して病原体の侵入を防ぎ生体防御に貢献すると考 えられている. L. cremoris FCに打いてもその発酵乳中 に含まれるEPSが小腸パイエル板細胞に作用すること が明らかとなっている ${ }^{13)}$. Hong ら ${ }^{19)}$ の方法に従ってマ ウスより調製したパイエル板細胞にEPSを添加培養し, その培養上清をマウス骨髄細胞に添加して骨䯣細胞増殖 活性を評価した。その結果, 骨髄細胞の増殖活性が認め られ，L. cremoris FCのEPSは腸管免疫活性を有する ことが明らかとなった，骨髄細胞は造血幹細胞の集合体 であることからL. cremoris FCはパイエル板を介して 抗体産生細胞の成熟に関与することが期待されるが, $L$. cremoris FCのSIgA 産生誘導メカニズムについては更 なる研究が必要である。また, 辻ら ${ }^{20)}$ の報告では, $L$. cremoris FC 菌体を免疫細胞に接触させた場合, 免疫賦 活活性の指標である IFN- $\gamma$ やナチュラルキラー活性が, 2,3 日の短期で, 他の乳酸菌細胞に比して大きく増大 したデー夕も得られている.

POMSによる心理状態の調查を実施したが, L. cremoris FCを含むヨーグルトの摂取による改善は認められな かった，一方，ストレス状態を反映する唾液コルチゾー ルは対照群では有意に増加したのに対し、ヨーグルト摂 取群では有意な増加は認められなかった。アスリートを
対象としたLactobacillus gasseri OLL2809の摂取試験で は, 唾液SIgAの分泌促進に伴って心理状態が改善され ることが示されている7 ${ }^{7,8)}$. L. cremoris FCを含むヨー グルトの摂取により唾液SIgAの分泌促進およびコルチ ゾールの上昇抑制が示されたので，心理状態へ作用する ことが期待されたが関連を明らかにすることは出来な かった，今回の試験では 1 群 7 名と少人数の被験者を対 象として実施したので，差が得られなかった可能性があ る. L. cremoris FCの心理状態への作用については, 更 なる研究が必要と考えられる。

本研究の限界は, ヨーグルトの対照食として牛乳を 用い, 被験者の盲検化を行わなかった点である。今回 の試験では乳酸菌以外の乳成分の影響を除外するため, 対照食として牛乳を用いた。 しかし、ヨーグルトは固 形，牛乳は液体と形状が異なるため，食品形態の違いが 結果に影響した可能性がある。また, 今回の試験食は $L$. cremoris FC抢よびヨーグルトスターターとして工業生 産に用いられるS. thermophilus ST117で製造した。 L. cremoris FCでは前述のと扔り EPSを産生し免疫調節力 が確かめられていることから, 今回の試験で得られた作 用もL. cremoris FCに由来すると考えられる。 しかしな がら，対照食としてS. thermophilus ST117のみで製造 したヨーグルトを試験食として用いるべきであった，今 後の検討では対照食をL. cremoris FCを含まないヨーグ ルトとし，二重盲検法により試験を実施しその効果を確 認したい。加えて, 唾液の採取方法でも正式な唾液採取 方法に従って採取を行う必要があると考えている.また, 運動負荷量についても，心拍数などの客観的デー夕もあ わせて測定する必要がある。

結論として, 強運動負荷時のアスリートにおいて，5 
日間のL. cremoris FCの連続摂取が唾液SIgA分泌を高 める可能性があることが示唆された。アスリートは日常 的に身体的, 精神的ストレスに曝され, 免疫力の低下に 伴う上気道感染リスクの増大などコンディションの低下 が問題となっている。今回の試験では 5 日間という短期 間のL. cremoris FCの摂取により，唾液SIgA分泌が高 まる可能性が示されたので, L. cremoris FCの継続的な 摂取が普段のアスリートのコンディショニングに有用で あることに加え, 短期間の強化練習時など高いストレス が負荷される際にも有用である可能性が示唆された。さ らなる詳細な検討を予定している。

\section{結語}

高校陸上長距離選手を対象に，5日間の強化練習期間 においてL. cremoris FCを含むヨーグルトの摂取が唾液 SIgA 分泌やコンディションに及ぼす影響について検討 した。その結果, L. cremoris FCの摂取により唾液 SIgA 分泌が高まる可能性が示唆された。 また，運動負荷によ る唾液コルチゾールの増加を抑制する可能性も見られ た.よって, L. cremoris FCはアスリートのコンディショ ン向上に有用な可能性があると考えられた。

\section{謝 辞}

本研究にご協力いただきました高校生陸上部員の皆様に 深く感謝いたします.

\section{利益相反}

本研究には, フジッコ株式会社の後藤弥生, 小阪英樹, 相 磯知里，鈴木利雄が著者となっている.

\section{引用文献}

1) Nieman DC, Johanssen LM, Lee JW, Arabatzis K. Infectious episodes in runners before and after the Los Angeles Marathon. J Sports Med Phys Fitness 30: 316-328, 1990.

2) Peters EM, Bateman ED. Ultramarathon running and URTI: an epidemiological survey. S Afr Med J 64: 582-584, 1983.

3) Neville V, Gleeson M, Folland JP. Salivary IgA as a risk factor for upper respiratory infections in elite professional athletes. Med Sci Sports Exerc 40: 1228-1236, 2008. doi: 10.1249/MSS.0b013e31816be9c3.

4) Nieman DC, Henson DA, Dumke CL, Lind RH, Shooter LR, Gross SJ. Relationship between salivary IgA secretion and upper respiratory tract infection following a 160-km race. J Sports Med Phys Fitness 46: 158162,2006

5）秋本崇之, 赤間高雄, 香田泰子, 和久貴洋, 林 栄輔, 龍野 美恵子, 杉浦弘一, 天野和彦, 河野一郎：高強度卜レーニ ングによる安静時唾液中分泌型 IgAの変動, 体力科学, 47: 245-251, 1998. doi: 10.7600/jspfsm1949.47.245.
6) 清水和弘, 相澤勝治, 鈴木なつ未, 久木留 毅, 木村文律, 赤間高雄, 目崎 登, 河野一郎：唾液中SIgAを用いた全 日本トップレスリング選手の急速減量時のコンディ ション評価, 日本臨床スポーツ医学会誌, 15: 441-447, 2007.

7) 花岡裕吉, 清水和弘, 鷲谷浩輔, 田村 明, 竹村雅裕, 古川 拓生, 宮本俊和, 渡部厚一, 赤間高雄 : MG2809乳酸菌の 摂取が大学ラグビー選手の口腔内免疫能に及ぼす影響, 体力科学, 64: 315-322, 2015. doi: 10.7600/jspfsm.64.315.

8) Sashihara T, Nagata M, Mori T, Ikegami S, Gotoh M, Okubo K, Uchida M, Itoh H. Effects of Lactobacillus gasseri OLL2809 and $\alpha$-lactalbumin on universitystudent athletes: a randomized, double-blind, placebocontrolled clinical trial. Appl Physiol Nutr Metab 38: 1228-1235, 2013. doi: 10.1139/apnm-2012-0490.

9) Cox AJ, Pyne DB, Saunders PU, Fricker PA. Oral administration of the probiotic Lactobacillus fermentum VRI-003 and mucosal immunity in endurance athletes. Br J Sports Med 44: 222-226, 2010. doi: 10.1136/ bjsm.2007.044628.

10) Kekkonen RA, Vasankari TJ, Vuorimaa T, Haahtela T, Julkunen I, Korpela R. The effect of probiotics on respiratory infections and gastrointestinal symptoms during training in marathon runners. Int J Sport Nutr Exerc Metab 17: 352-363, 2007. doi: 10.1123/ijsnem.17.4.352.

11) Ishida $T$, Yokota $A$, Umezawa $Y$, Toda $T$, Yamada $K$. Identification and characterization of lactococcal and Acetobacter strains isolated from traditional Caucasusian fermented milk. J Nutr Sci Vitaminol (Tokyo) 51: 187-193, 2005. doi: 10.3177/jnsv.51.187.

12) Maruo $T$, Gotoh $Y$, Nishimura $H$, Ohashi S, Toda T, Takahashi K. Oral administration of milk fermented with Lactococcus lactis subsp. cremoris FC protects mice against influenza virus infection. Lett Appl Microbiol 55: 135-140, 2012. doi: 10.1111/j.1472765X.2012.03270.x.

13) Gotoh Y, Suzuki S, Amako M, Kitamura S, Toda T. Effect of orally administered exopolysaccharides produced by Lactococcus lactis subsp. cremoris FC on a mouse model of dermatitis induced by repeated exposure to 2, 4, 6-trinitro-1-chlorobenzene. J Funct Foods 35: 43-50, 2017. doi: 10.1016/j.jff.2017.04.045.

14) Shimizu K, Sato H, Suga Y, Yamahira S, Toba M, Hamuro K, Kakumoto K, Kohda N, Akama T, Kono I, Kuno S. The effects of Lactobacillus pentosus strain b240 and appropriate physical training on salivary secretory IgA levels in elderly adults with low physical fitness: A randomized, double-blind, placebocontrolled trial. J Clin Biochem Nutr 54: 61-66, 2014. doi: 10.3164 /jcbn.13-62.

15）岸 和正, 小谷吉史, 山平聡子, 戸羽正道, 岡松 洋, 三原修 一, 鶴田容子, 竹原美沙, 赤星覀朱香, 南 久則 : Lactobacillus plantarum ONRICb0240は健康成人の唾液 IgA 量を高める, 日本乳酸菌学会誌, 17: 132-137, 2006. doi: 10.4109/jslab.17.132.

16) Gleeson M, Bishop NC, Oliveira M, Tauler P. Daily 
probiotic's (Lactobacillus casei Shirota) reduction of infection incidence in athletes. Int J Sport Nutr Exerc Metab 21: 55-64, 2011. doi: 10.1123/ijsnem.21.1.55.

17) Mori M, Kosaka H, Terai M, Mori H, Bennno Y, Yamori M, Hirota H, Yamori Y, Toda T. Chapter 13, Effects of "Caspian Sea yogurt" (fermented milk with Lactococcus lactis subsp. cremoris $\mathrm{FC}$ ) on the health of Japanese people - Lessons from traditional Western food culture. Report of building food culture and education for longevity 20-year CARDIAC Study Symposium, UNESCO, Paris, 105-112, 2005.

18) Kotani $Y$, Kunisawa J, Suzuki Y, Sato I, Saito T, Toba M, Kohda N, Kiyono H. Role of Lactobacillus pentosus Strain b240 and the Toll-like receptor 2 axis in Pey- er's patch dendritic cell-mediated immunoglobulin A enhancement. PLoS One 9: e91857, 2014. doi: 10.1371/ journal.pone.0091857.

19) Hong $T$, Matsumoto T, Kiyohara H, Yamada H. Enhanced production of hematopoietic growth factors through T cell activation in Peyer's patches by oral administration of Kampo (Japanese herbal) medicine, "Juzen-Taiho-To". Phytomedicine 5: 353-360, 1998.

20) Kosaka A, Yan H, Ohashi S, Gotoh Y, Sato A, Tsutsui H, Kaisho T, Toda T, Tsuji NM. Lactococcus lactis subsp. cremoris $\mathrm{FC}$ triggers IFN- $\gamma$ production from $\mathrm{NK}$ and $\mathrm{T}$ cells via $\mathrm{IL}-12$ and IL-18. Int Immunopharmacol 14: 729-733, 2012. doi: 10.1016/j.intimp.2012.10.007. 